Article

\title{
The Role of Ammonium Chloride in the Powder Thermal Diffusion Alloying Process on a Magnesium Alloy
}

\author{
Dongzhu Lu 1,2,3,*®D, Quantong Jiang 1,2,3, Meng Zheng 1,2,3, Jie Zhang 1,2,3, \\ Yanliang Huang 1,2,3 and Baorong Hou 1,2,3 \\ 1 CAS Key Laboratory of Marine Environmental Corrosion and Bio-fouling, Institute of Oceanology, \\ Chinese Academy of Science, Qingdao 266071, China; jiangquantong@qdio.ac.cn (Q.J.); \\ mzheng@qdio.ac.cn (M.Z.); zhangjie@qdio.ac.cn (J.Z.); hyl@qdio.ac.cn (Y.H.); brhou@qdio.ac.cn (B.H.) \\ 2 Open Studio for Marine Corrosion and Protection, Pilot National Laboratory for Marine Science and \\ Technology (Qingdao), Qingdao 266237, China \\ 3 Center for Ocean Mega-Science, Chinese Academy of Sciences, Qingdao 266071, China \\ * Correspondence: ldz@qdio.ac.cn; Tel.: +86-532-8289-8743
}

Received: 22 March 2019; Accepted: 13 April 2019; Published: 15 April 2019

check for updates

\begin{abstract}
The powder thermal diffusion alloying method could be utilized to fabricate Al-rich intermetallic coatings on magnesium alloys in the air. While the role of ammonium chloride powder in the diffusion alloying source is still to be investigated. This research took the AZ91D magnesium alloy as the substrate. Diffusion sources with various powders were utilized as the diffusion source. Microstructure observation and phase identification were enrolled to investigate the role of the ammonium chloride powder in the diffusion alloying process. Results indicate that $\mathrm{HCl}$ gas could turn some solid $\mathrm{Al}$ powder into gaseous $\mathrm{AlCl}_{3}$ to enhance the transport of active $\mathrm{Al}$ atoms, moreover, it reacts with the dense $\mathrm{MgO}$ film and converts it to a loose one, which enables the $\mathrm{AlCl}_{3}$ gas to penetrate $\mathrm{MgO}$ and arrive the matrix to form a protective coating. Furthermore, the ammonium chloride content should be confined to $10 \mathrm{wt}$. \% of the diffusion alloying source. Too much ammonium chloride powder would result in a worse intermetallic coating.
\end{abstract}

Keywords: magnesium alloy; ammonium chloride; diffusion; coating; powder

\section{Introduction}

Magnesium alloys are easy to be corroded and this limits their utilization [1-4]. To protect magnesium alloys from serious corrosion, various methods are raised. For example, magnesium alloys could be covered with coatings which are much more corrosion resistant [5-7].

By the diffusion alloying method, metallic atoms could be added to the matrix of magnesium alloys continuously for the corrosion resistant coatings to form [8-14]. Most of these diffusion alloyed coatings are obtained in a vacuum or inert atmosphere. While utilizing ammonium chloride as an activator, such a diffusion alloying process could be carried out even in the air $[15,16]$.

The as-diffusion alloyed Al-rich intermetallic coating usually composed of two phases, a light phase and a dark phase [3,4,14-16]. The light phase has a network shape, and the dark phase is co-mingled in the light phase. The Al content of the light phase is much higher than that of the dark phase. The light phase is mainly composed of $\mathrm{Mg}_{17} \mathrm{Al}_{12}$, while the dark phase is mainly $\alpha-\mathrm{Mg}$.

The Al-rich intermetallic layer integrates with the magnesium alloy matrix by metallurgical bonding, and such bonding could improve the adhesion strength greatly [4]. Compared with an ordinary specimen, the diffusion alloyed magnesium alloy specimen has better corrosion resistance 
due to the formation of the Al-rich intermetallic layer $[4,8,9,11,12]$. The hardness of the Al-rich intermetallic layer is also higher than that of the magnesium alloy substrate $[4,8,14]$.

It is commonly assumed that solid diffusion dominates the overall diffusion alloying process. While, after addition of some $\mathrm{NH}_{4} \mathrm{Cl}$ powder as the activator, the mass transport process could be different from the traditional diffusion alloying process without the activator. Thus, it is meaningful to investigate mass transport in a powder thermal diffusion alloying process in the air.

Meanwhile, as the ammonium chloride powder could promote the formation of the intermetallic layer on magnesium alloys, how to utilize the ammonium chloride powder effectively is still an issue to be discussed. Generally, if the relative content of ammonium chloride powder in the mixed powder increases continuously, three circumstances could be encountered [17-20]. First, the increased ammonium chloride content would promote the formation of the intermetallic coating further. Second, the increased ammonium chloride content would have little effect on the intermetallic coatings. Third, the increased ammonium chloride content would have a negative effect on the intermetallic coating, in other words, both the thickness and completeness of the intermetallic coatings would be worse.

In this research, different diffusion alloying systems were designed and tested to clarify the role of ammonium chloride in the diffusion alloying process on the AZ91D magnesium alloy specimens. Furthermore, to utilize $\mathrm{NH}_{4} \mathrm{Cl}$ powder effectively, powder thermal diffusion alloying processes with various $\mathrm{NH}_{4} \mathrm{Cl}$ contents in the diffusion source were carried out to fabricate Al-rich intermetallic coatings on the AZ91D magnesium alloy specimens. It is hoped that the corresponding results would be helpful for utilizing $\mathrm{NH}_{4} \mathrm{Cl}$ powder more rationally to fabricate better intermetallic coatings, to save materials and to alleviate air pollution and device degradation.

\section{Experimental Details}

An as-cast AZ91D magnesium alloy with the chemical composition shown in Table 1 was utilized as the substrate for packed powder diffusion alloying treatment. Samples with a dimension of $15 \mathrm{~mm} \times 10 \mathrm{~mm} \times 3 \mathrm{~mm}$ were cut from the magnesium alloy sheets with an electrical discharge cutting machine (Posittec, Suzhou, China) for experiments. These specimens were polished with SiC papers to 1000 grit, rinsed with alcohol, and then dried up.

Table 1. The chemical composition of the AZ91D magnesium alloy substrate.

\begin{tabular}{ccccccccc}
\hline Element (wt. \%) & Al & Zn & Mn & Si & Fe & Cu & Ni & Mg \\
\hline AZ91D & 9.1 & 0.52 & 0.26 & 0.03 & 0.001 & 0.014 & 0.001 & Balance \\
\hline
\end{tabular}

As the diffusion source, the mixed powder was composed of $\mathrm{Al}$ powder, $\mathrm{Al}_{2} \mathrm{O}_{3}$ powder and $\mathrm{NH}_{4} \mathrm{Cl}$ powder. The size of the as utilized pure Al powder varies from tens of micrometers to hundreds of micrometers as shown in Figure $1 \mathrm{a}$. The as utilized $\mathrm{Al}_{2} \mathrm{O}_{3}$ powder has a spherical morphology, the diameter of which varies from 100 to $300 \mu \mathrm{m}$ as shown in Figure $1 \mathrm{~b}$. The as utilized $\mathrm{NH}_{4} \mathrm{Cl}$ powder has a cubic morphology and a size which could even approach $1000 \mu \mathrm{m}$ as shown in Figure 1c. Without specification, there would always be $10 \mathrm{~g}$ of $\mathrm{Al}$ powder, $10 \mathrm{~g} \mathrm{Al}_{2} \mathrm{O}_{3}$ powder in the diffusion source. In this research, to investigate the effect of the $\mathrm{NH}_{4} \mathrm{Cl}$ powder, the weight of $\mathrm{NH}_{4} \mathrm{Cl}$ powder in the diffusion source varies. In different schemes, the contents of $\mathrm{NH}_{4} \mathrm{Cl}$ powder were set to be 1 , $2,3,4$, and $5 \mathrm{~g}$ individually. Then the $\mathrm{Al}$ powder, the $\mathrm{Al}_{2} \mathrm{O}_{3}$ powder and the $\mathrm{NH}_{4} \mathrm{Cl}$ powder were mixed together.

The mixed powder was put into a $30 \mathrm{~mL}$ ceramic crucible and the AZ91D magnesium alloy specimens were buried in the mixed powder. After the temperature in an ordinary resistance furnace reached $430^{\circ} \mathrm{C}$ and was kept stable for a certain period, the fulfilled crucible was put into the furnace as quickly as possible and kept at $430^{\circ} \mathrm{C}$ for $2 \mathrm{~h}$ for the diffusion alloying process to proceed. The whole diffusion alloying process was carried out in the air, neither vacuum nor inert gas was utilized. 
When the diffusion alloying process finished, the specimens were taken out from the furnace and cooled down in the air.
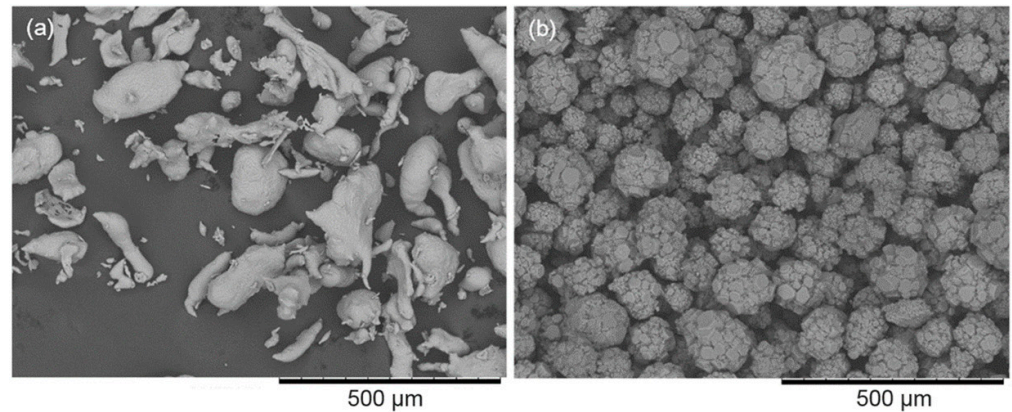

Figure 1. The as-utilized powder (a) the pure $\mathrm{Al}$ powder, (b) the $\mathrm{Al}_{2} \mathrm{O}_{3}$ powder, (c) the $\mathrm{NH}_{4} \mathrm{Cl}$ powder.

After the residual mixed powder was shaken off, the as-diffusion alloyed specimens were washed in running water and alcohol successively, and then dried up. Cross sections of specimens were obtained with a saw and then polished and etched for microstructure observation. Two etchants were utilized. One of which composed of $4 \mathrm{~mL}$ of nitric acid and $96 \mathrm{~mL}$ of alcohol. The other etchant composed of $6 \mathrm{~g}$ picric acid, $10 \mathrm{~mL}$ of glacial acetic acid, $10 \mathrm{~mL}$ of distilled water, and $70 \mathrm{~mL}$ of alcohol. The polished cross-sections of the specimens were etched until the intermetallic phases showed up clearly on the specimen surface. Then, specimens were washed with alcohol and dried up. Morphology of the cross sections of the as-diffusion alloyed specimens was observed by a tabletop microscope (TM3030, Hitachi, Tokyo, Japan) and a scanning electronic microscope (SEM, S-3400N, Hitachi, Tokyo, Japan). The phase identification was carried out utilizing an X-ray diffractometer (Ultima IV, Rigaku, Tokyo, Japan). The Gibbs energies were calculated by a software HSC 6.0.

\section{Results and Discussion}

\subsection{Formation of the Intermetallic Coating on the AZ91D Magnesium Alloy}

A coating was obtained by the compact powder diffusion alloying process with a diffusion source containing $1 \mathrm{~g}$ of $\mathrm{NH}_{4} \mathrm{Cl}, 10 \mathrm{~g}$ of $\mathrm{Al}$ powder, $10 \mathrm{~g}$ of $\mathrm{Al}_{2} \mathrm{O}_{3}$ powder, and a cross-section of the as-diffusion alloyed specimen with the coating is shown in Figure 2a. It could be figured out that the thickness of the coating varies from tens of micrometers to one hundred micrometers. Moreover, as shown in Figure 3, the Mg element and the $\mathrm{Al}$ element coexist in the as-diffusion alloyed coating, which indicates that this coating is an intermetallic coating. Meanwhile, the $\mathrm{Al}$ content in the network-shape phase is obviously higher than that in the matrix, which indicates that the intermetallic coating is rich in $\mathrm{Al}$. Additionally, there is mainly the $\mathrm{Mg}_{17} \mathrm{Al}_{12}$ phase and magnesium solid solution in the intermetallic layer [15].

The formation process of the as-diffusion alloyed intermetallic layer could be described as follows. At the beginning of the diffusion alloying process, the magnesium alloy specimen and the mixed powder contacted directly as shown in Figure $2 \mathrm{~b}$. As the diffusion alloying process went on, the $\mathrm{NH}_{4} \mathrm{Cl}$ powder in the diffusion source decomposed into $\mathrm{NH}_{3}$ gas and $\mathrm{HCl}$ gas, and the $\mathrm{HCl}$ gas reacted with the diffusion source to produce gaseous $\mathrm{AlCl}_{3}$. Meanwhile, on the surface of the magnesium alloy specimen, a loose $\mathrm{MgO}$ film formed. The $\mathrm{AlCl}_{3}$ gas went through the loose $\mathrm{MgO}$ film to arrive at the magnesium alloys substrate. Thus, $\mathrm{Al}$ atoms were added continuously into the magnesium alloy's matrix. After the relative $\mathrm{Al}$ content on the magnesium alloy surface reached a limit, the local melt emerged according to the phase diagram [16] as shown in Figure 2c. After the diffusion alloying process, the Al-rich melt cooled down gradually, the magnesium solid solution phase and the $\mathrm{Mg}_{17} \mathrm{Al}_{12}$ phase solidified one after another [21]. Thus, a eutectic Al-rich coating is formed on the magnesium alloy specimen surface as shown in Figure 2d. 

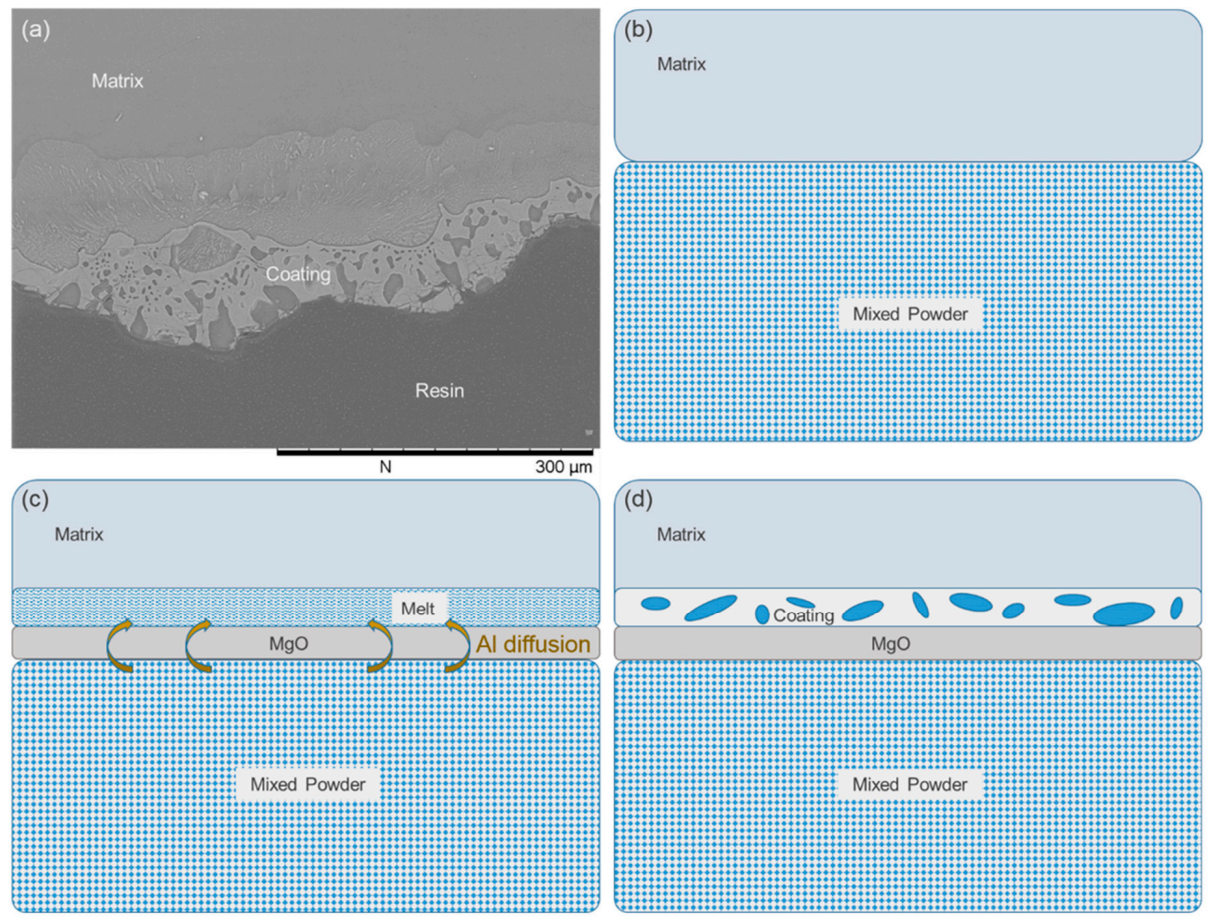

Figure 2. The microphotograph of the as-fabricated coating (a) and schematic diagrams to illustrate the formation process of the coating $(\mathbf{b}-\mathbf{d})$.
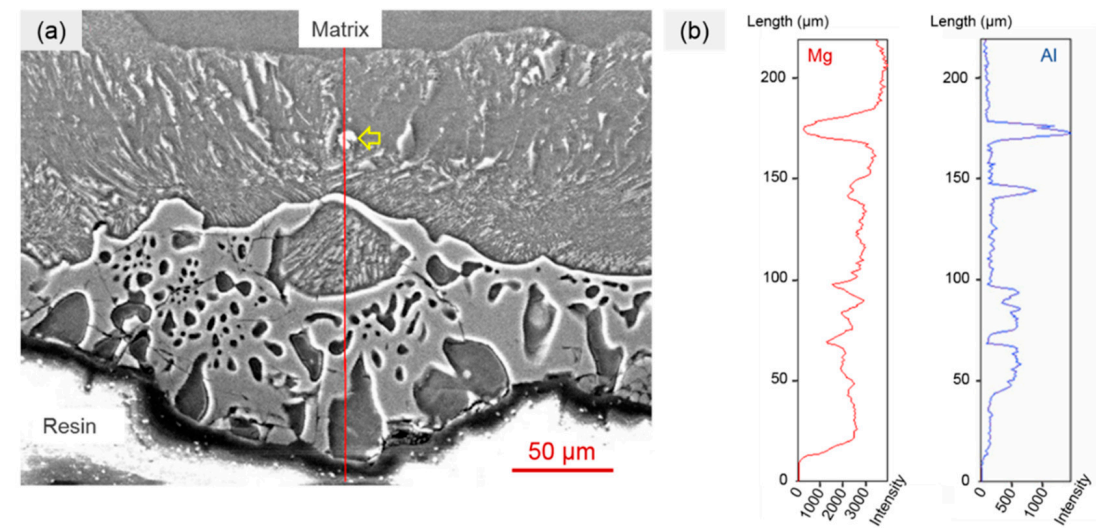

Figure 3. The cross-section of partial as-diffusion alloyed coating (a) and relative element distribution (b) on the line shown in (a). The arrow in (a) indicates an external Al-rich particle.

\subsection{Ammonium Chloride Could Keep the Surface of the Magnesium Alloy Matrix Fresh}

It is reported that [22] at the beginning of the oxidation process of magnesium alloys, a compact layer would emerge at the magnesium alloy surface, and such a dense layer could separate the diffusion source from the magnesium alloy matrix, thus the diffusion of active metal atoms and the growth of the intermetallic layer on magnesium alloy surface is interfered by a dense film as illustrated in Figure 4 .

Chemical reactions involved in the powder thermal diffusion alloying process of our work are shown below. The Gibbs energies of these chemical reactions are shown in Figure 5.

$$
\begin{gathered}
\mathrm{NH}_{4} \mathrm{Cl}=\mathrm{NH}_{3}(\mathrm{~g})+\mathrm{HCl}(\mathrm{g}) \\
2 \mathrm{Al}+6 \mathrm{HCl}(\mathrm{g})=2 \mathrm{AlCl}_{3}(\mathrm{~g})+3 \mathrm{H}_{2}(\mathrm{~g}) \\
\mathrm{MgO}+2 \mathrm{HCl}(\mathrm{g})=\mathrm{MgCl}_{2}+\mathrm{H}_{2} \mathrm{O}(\mathrm{g}) \\
\mathrm{MgCl}_{2}+\mathrm{H}_{2} \mathrm{O}(\mathrm{g})=\mathrm{Mg}(\mathrm{OH}) \mathrm{Cl}+\mathrm{HCl}(\mathrm{g})
\end{gathered}
$$




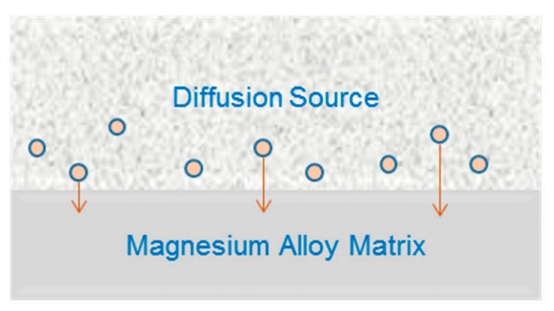

(a) In Vacuum or Inert Atmosphere

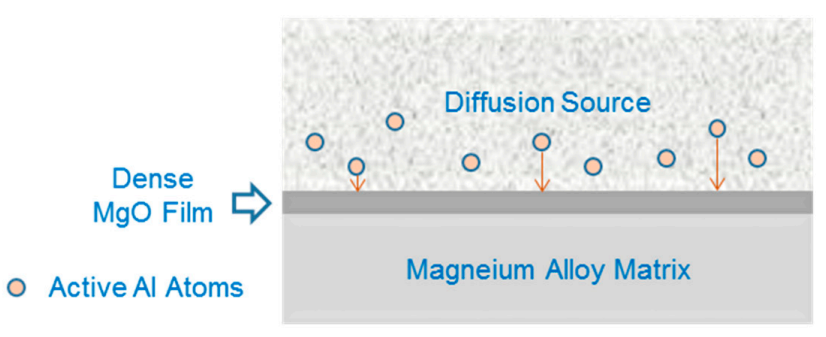

(b) In Air

Figure 4. The traditional powder thermal diffusion alloying process on magnesium alloys in a vacuum or inert atmosphere (a) and in the air (b).

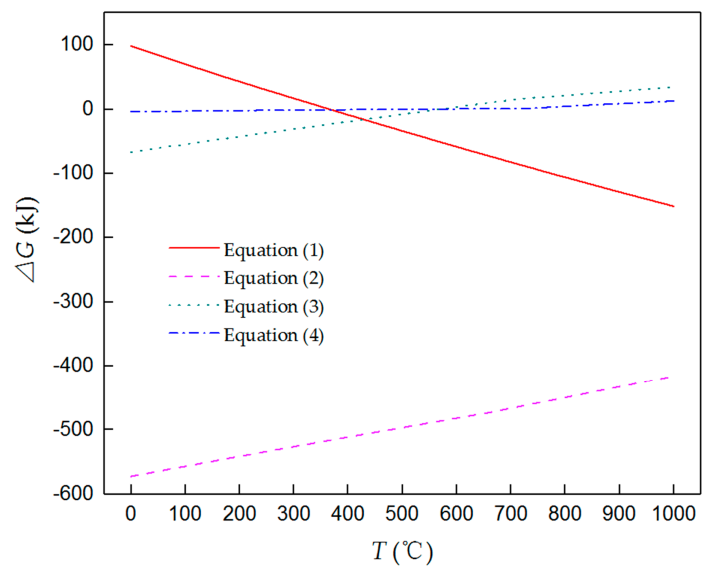

Figure 5. The Gibbs energies of some chemical reactions in a thermal diffusion alloying process.

As the $\mathrm{HCl}$ gas which decomposed from the ammonium chloride powder could turn the pure $\mathrm{Al}$ powder into $\mathrm{AlCl}_{3}$ gas as described in Equation (2), the diffusion source could then be changed from a mixture of $\mathrm{Al}, \mathrm{Al}_{2} \mathrm{O}_{3}$ and $\mathrm{NH}_{4} \mathrm{Cl}$ into a mixture of $\mathrm{AlCl}_{3}$ and $\mathrm{NH}_{4} \mathrm{Cl}$. Hence, a diffusion alloying process with $1 \mathrm{~g}$ of $\mathrm{AlCl}_{3}$ and $1 \mathrm{~g}$ of $\mathrm{NH}_{4} \mathrm{Cl}$ as the diffusion source was carried out to testify whether such a new mixture could make an Al-rich intermetallic layer form. Meanwhile, in this experiment, a layer of $\mathrm{SiO}_{2}$ powder separated the AZ91D magnesium alloy matrix from the diffusion source which was composed of $\mathrm{AlCl}_{3}$ and $\mathrm{NH}_{4} \mathrm{Cl}$ to investigate whether the $\mathrm{AlCl}_{3}$ gas could pass through the $\mathrm{SiO}_{2}$ barrier and arrive at the magnesium alloy matrix to form a coating. Schematic diagram of the diffusion alloying system is shown in Figure 6a.
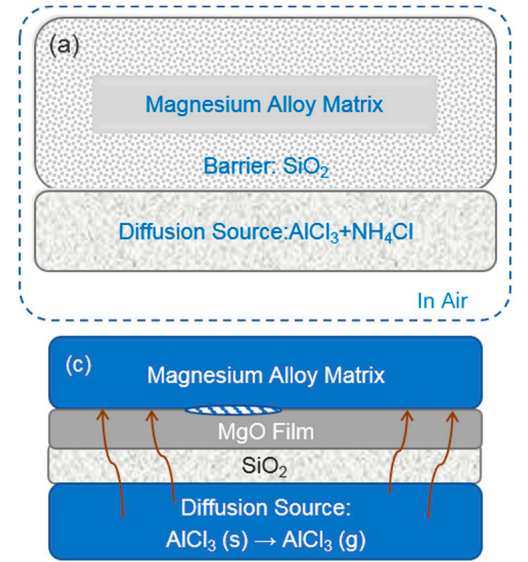

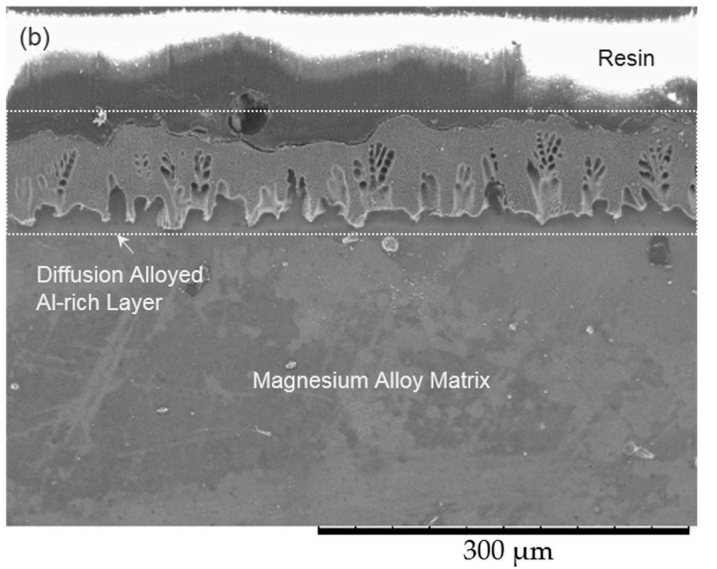

$300 \mu \mathrm{m}$

Figure 6. (a) The illustration of the diffusion alloying system to prove the existence of vapor transport; (b) The as-diffusion alloyed intermetallic layer utilizing the diffusion alloying system shown in (a);

(c) The source and movement of the $\mathrm{AlCl}_{3}$ gas which carrying active $\mathrm{Al}$ atoms. 
After the diffusion alloying process, an intermetallic coating formed on the magnesium alloy specimen as shown in Figure 6b. The thickness of the coating is near $100 \mu \mathrm{m}$. The mechanism could be explained as shown in Figure 6c. When heated up, the solid $\mathrm{AlCl}_{3}$ powder became $\mathrm{AlCl}_{3}$ gas. The $\mathrm{AlCl}_{3}$ gas could penetrate the $\mathrm{SiO}_{2}$ layer and the $\mathrm{MgO}$ film, and arrive at the magnesium alloy matrix to form an intermetallic coating.

An experiment was carried out to clarify whether it is possible to simplify the diffusion source which was composed of $\mathrm{AlCl}_{3}$ and $\mathrm{NH}_{4} \mathrm{Cl}$ further to a new diffusion source which was only composed the $\mathrm{AlCl}_{3}$ powder. As shown in Figure 7a, there was only the $\mathrm{AlCl}_{3}$ powder in the diffusion source. A layer of $\mathrm{SiO}_{2}$ was also utilized to separate the magnesium alloy matrix from the diffusion source. After the diffusion alloying process, it is hard to find an intermetallic layer on the magnesium alloy specimen as shown in Figure $7 \mathrm{~b}$. This result illustrates that the $\mathrm{NH}_{4} \mathrm{Cl}$ powder is important in a powder thermal diffusion alloying process on a magnesium alloy matrix. As shown in Figure $7 c$, if the diffusion source is lacking $\mathrm{NH}_{4} \mathrm{Cl}$, a compact $\mathrm{MgO}$ film could form on the surface of the magnesium alloy specimen. Thanks to the decomposition of the $\mathrm{NH}_{4} \mathrm{Cl}$ powder, the $\mathrm{HCl}$ gas could turn a compact $\mathrm{MgO}$ film into a loose one as described in Equation (3) and (4), thus the $\mathrm{AlCl}_{3}$ gas has the chance to penetrate the loose $\mathrm{MgO}$ film to arrive at the magnesium alloy matrix.
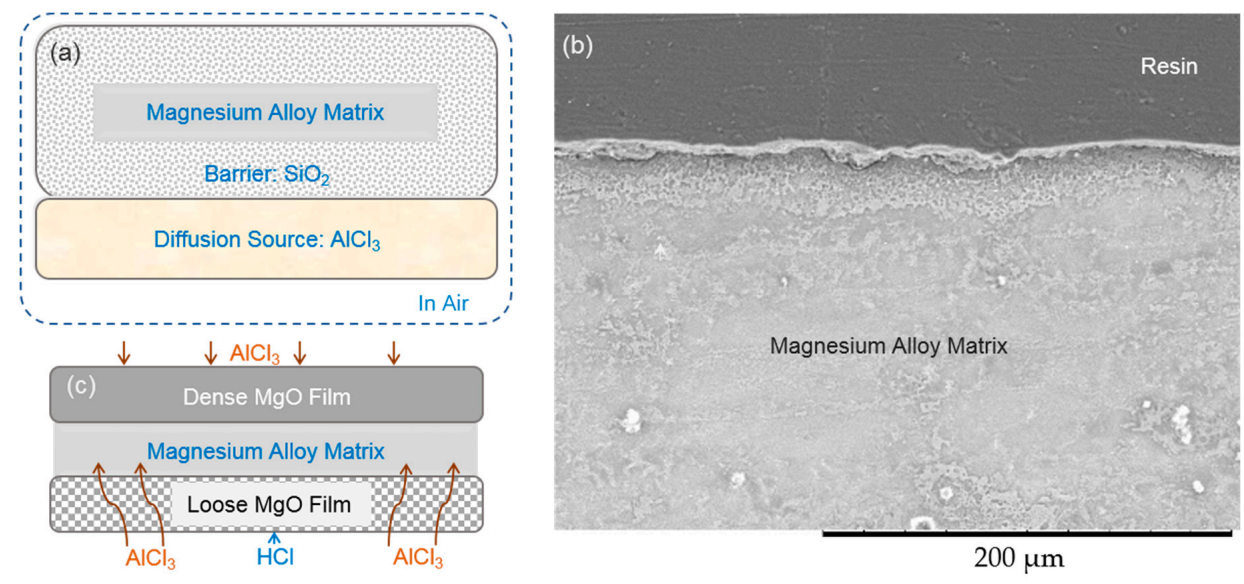

Figure 7. (a) The illustration of the powder thermal diffusion alloying system to investigate the effect of $\mathrm{NHCl}_{4}$ on the $\mathrm{MgO}$ film; (b) Cross section of the as-diffusion alloyed specimen utilizing the diffusion system shown in (a); (c) Effect of the $\mathrm{HCl}$ gas on the $\mathrm{MgO}$ film.

\subsection{The Upper Content Limit of the Ammonium Chloride in a Diffusion Alloying Process}

Figure 8 shows the $\mathrm{XRD}$ patterns of the as-diffusion alloyed specimens with various diffusion sources containing $10 \mathrm{~g} \mathrm{Al}$ powder, $10 \mathrm{~g} \mathrm{Al}_{2} \mathrm{O}_{3}$ powder together with 1, 2, 3, $4,5 \mathrm{~g}$ of $\mathrm{NH}_{4} \mathrm{Cl}$ powder respectively. Peaks related to the $\mathrm{Mg}$ solid solution, $\mathrm{MgO}$, and $\mathrm{Mg}_{17} \mathrm{Al}_{12}$ could be identified. The existence of the $\mathrm{Mg}$ solid solution and $\mathrm{Mg}_{17} \mathrm{Al}_{12}$ is consistent with the result shown in Figure 2a. Additionally, the existence of $\mathrm{MgO}$ is attributed to the preferential oxidation of $\mathrm{Mg}$ atoms [22,23]. It could be figured out that as the $\mathrm{NH}_{4} \mathrm{Cl}$ content increases from 1 to $3 \mathrm{~g}$ gradually, the peaks of the $\mathrm{Mg}_{17} \mathrm{Al}_{12}$ phase in the XRD pattern became smaller and smaller, which means a continuously reduced quantity of the intermetallic layer. When the $\mathrm{NH}_{4} \mathrm{Cl}$ content in the diffusion source passes over $3 \mathrm{~g}$, the peaks of the $\mathrm{Mg}_{17} \mathrm{Al}_{12}$ phase could hardly be figured out, which means the quantity of the intermetallic phase on the magnesium specimens is limited. Thus, under the condition that there is $10 \mathrm{~g}$ of $\mathrm{Al}$ powder and $10 \mathrm{~g}$ of $\mathrm{Al}_{2} \mathrm{O}_{3}$ powder in the diffusion source, the content of the $\mathrm{NH}_{4} \mathrm{Cl}$ powder is suggested to be no more than $2 \mathrm{~g}$ according to the XRD patterns shown in Figure 8. More generally, the weight of the $\mathrm{NH}_{4} \mathrm{Cl}$ powder is suggested to be no more than $10 \%$ of the overall weight of the diffusion source.

As shown in Figure 9, after the powder thermal diffusion alloying process with a diffusion source which was composed of $5 \mathrm{~g}$ of $\mathrm{NH}_{4} \mathrm{Cl}$ powder, $10 \mathrm{~g}$ of $\mathrm{Al}$ powder and $10 \mathrm{~g}$ of $\mathrm{Al}_{2} \mathrm{O}_{3}$ powder, both the 
domain and the thickness of the intermetallic layer shrank obviously compared to that which was shown in Figure 2a. It is rare to find an intermetallic zone on the AZ91D magnesium alloy specimen surface. Figure 9a shows that there are even some local intermetallic zones occasionally, though their sizes are limited. The size of the local intermetallic zone as shown in Figure 9a is about $100 \mu \mathrm{m}$ in length and the maximum thickness is around $30 \mu \mathrm{m}$. Both the size and the thickness of the intermetallic zone are unparalleled to that which is fabricated with the diffusion source, which contains $1 \mathrm{~g}$ of $\mathrm{NH}_{4} \mathrm{Cl}$. Figure $9 b$ shows that it is rare to find an intermetallic zone at the specimen surface.

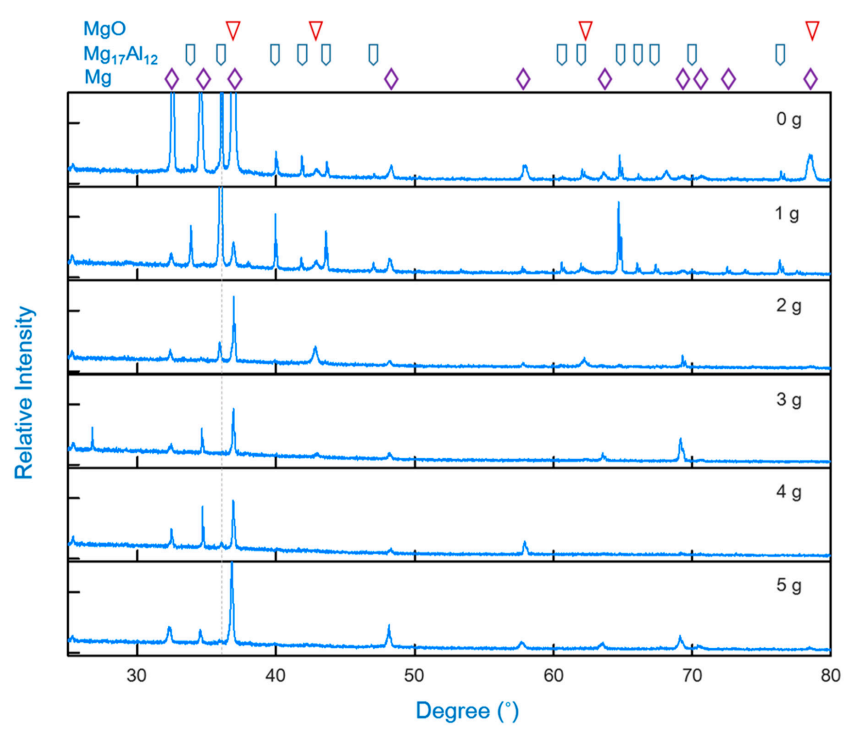

Figure 8. The $x$-ray diffraction $(\mathrm{XRD})$ patterns of specimens which underwent various diffusion alloying processes with an $\mathrm{NH}_{4} \mathrm{Cl}$ content of $1,2,3,4,5 \mathrm{~g}$, respectively in the diffusion source. The triangles, pentagons, and quadrangles mark characteristic peaks of $\mathrm{MgO}, \mathrm{Mg}_{17} \mathrm{Al}_{12}$ and $\mathrm{Mg}$ respectively.
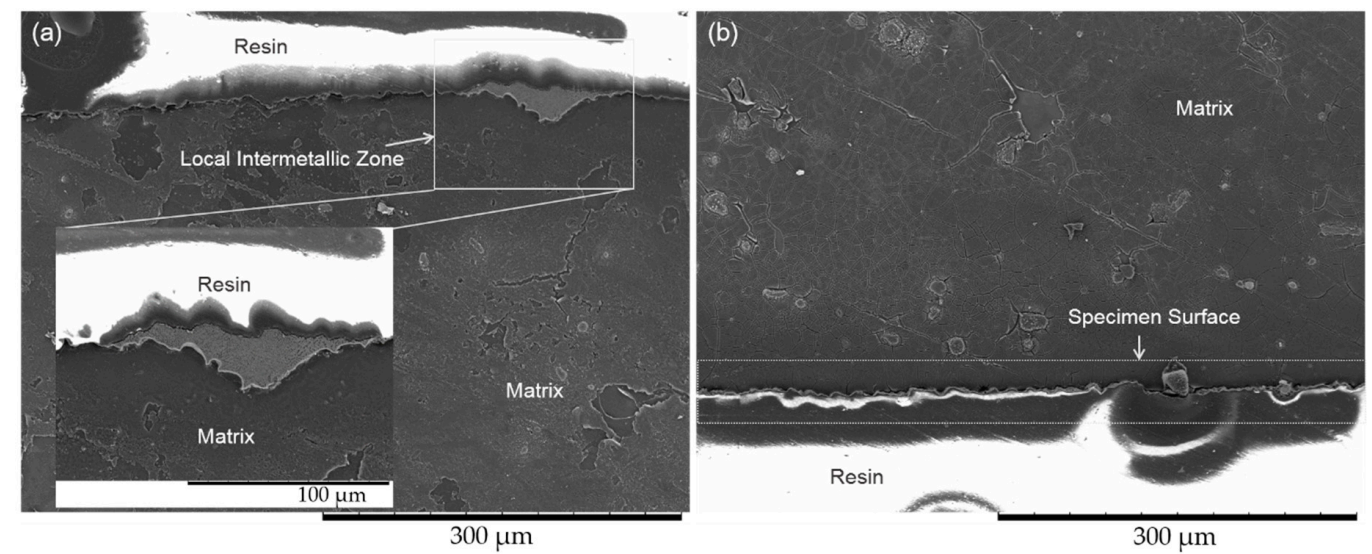

Figure 9. The cross sections of the as-diffusion alloyed intermetallic layer fabricated with the diffusion source containing $5 \mathrm{~g}$ of $\mathrm{NH}_{4} \mathrm{Cl}$ powder, $10 \mathrm{~g}$ of $\mathrm{Al}$ powder and $10 \mathrm{~g}$ of $\mathrm{Al}_{2} \mathrm{O}_{3}$ powder. Few intermetallic zones with limited sizes (a) could be found on the cross sections and most of the specimen surface is without any coating (b).

To investigate the effect of excess $\mathrm{NH}_{4} \mathrm{Cl}$ powder further, a contrast test was conducted. Initially, an as-diffusion alloyed specimen was obtained by a powder thermal diffusion alloying process with $1 \mathrm{~g}$ of $\mathrm{NH}_{4} \mathrm{Cl}$ powder, $10 \mathrm{~g}$ of $\mathrm{Al}$ powder and $10 \mathrm{~g}$ of $\mathrm{Al}_{2} \mathrm{O}_{3}$ powder as the diffusion source at $430{ }^{\circ} \mathrm{C}$ for $2 \mathrm{~h}$. Then, the as-diffusion alloyed specimen was cut into two pieces, one of which was observed by a scanning electron microscope directly and the other piece underwent another heating process which was carried out at $430{ }^{\circ} \mathrm{C}$ for $2 \mathrm{~h}$, the diffusion source of which contained $20 \mathrm{~g}$ of $\mathrm{SiO}_{2}$ powder and $3 \mathrm{~g}$ of $\mathrm{NH}_{4} \mathrm{Cl}$ powder. No $\mathrm{Al}$ powder or $\mathrm{Al}_{2} \mathrm{O}_{3}$ powder was involved in the second diffusion source. 
Since no $\mathrm{Al}$ atoms were added into the intermetallic layer, the effect of the excess $\mathrm{NH}_{4} \mathrm{Cl}$ powder on the as-formed intermetallic layer would be much more pronounced.

As shown in Figure 10a, the thickness of the intermetallic layer on the original specimen was around $100 \mu \mathrm{m}$ and the intermetallic layer was continuous and relatively complete. While, as shown in Figure 10b, after another heat treatment with excess $\mathrm{NH}_{4} \mathrm{Cl}$ powder, only a few local intermetallic zones are found on the magnesium alloy specimen surface, the thickness of the local intermetallic zone is no more than $50 \mu \mathrm{m}$. Moreover, the as-eroded specimen has a much more curved surface. This confirms that the excess $\mathrm{NH}_{4} \mathrm{Cl}$ powder could deteriorate the newly formed intermetallic layer, hence, both the thickness and the domain of the intermetallic layer was reduced. Hence, to fabricate a considerable intermetallic layer on the magnesium alloys by the powder thermal diffusion alloying method in the air, the content of the $\mathrm{NH}_{4} \mathrm{Cl}$ powder should be limited in a reasonable region.
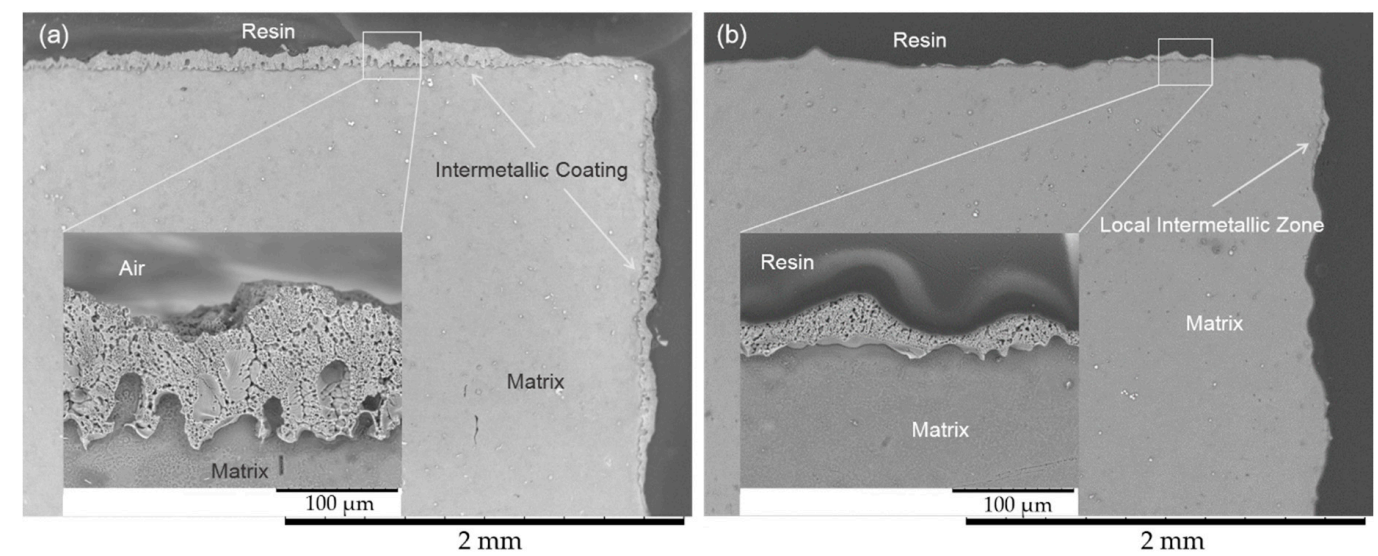

Figure 10. (a) The as-diffusion alloyed intermetallic layer obtained with $1 \mathrm{~g}$ of $\mathrm{NH}_{4} \mathrm{Cl}, 10 \mathrm{~g}$ of $\mathrm{Al}$ powder and $10 \mathrm{~g}$ of $\mathrm{Al}_{2} \mathrm{O}_{3}$ powder as the diffusion source; (b) The intermetallic layer on the specimen which not only underwent the diffusion alloying process in (a) but also underwent another heat treatment at $430{ }^{\circ} \mathrm{C}$ for $2 \mathrm{~h}$ with $20 \mathrm{~g}$ of $\mathrm{SiO}_{2}$ and $3 \mathrm{~g}$ of $\mathrm{NH}_{4} \mathrm{Cl}$ in the diffusion source further.

Based on the formation mechanism of the intermetallic coatings on magnesium alloys, the effect of the excess $\mathrm{NH}_{4} \mathrm{Cl}$ powder on the intermetallic coatings could be deduced. As the $\mathrm{NH}_{4} \mathrm{Cl}$ powder would decompose into $\mathrm{NH}_{3}$ gas and $\mathrm{HCl}$ gas, abundant $\mathrm{NH}_{4} \mathrm{Cl}$ powder would result in massive $\mathrm{NH}_{3}$ gas and excess $\mathrm{HCl}$ gas, which would dilute the metallic halide gas and this is not preferred by the diffusion alloying process. Meanwhile, the move of the bulk gases has the potential to cause the mixed powder to vibrate, and some particles would even be blown up. Moreover, excess $\mathrm{HCl}$ gas may react with the metallic atoms both in the substrate and in the intermetallic layer and cause erosion. Hence, excess ammonium chloride resulted in a worse intermetallic layer and could even cause material waste, device degradation, and air pollution furthermore.

\section{Conclusions}

To fabricate a metallic coating on magnesium alloys by the powder thermal diffusion alloying process in the air, the addition of ammonium chloride as an activator in the diffusion source is helpful. The $\mathrm{NH}_{4} \mathrm{Cl}$ powder could decompose into $\mathrm{NH}_{3}$ gas and $\mathrm{HCl}$ gas. $\mathrm{HCl}$ gas could react with $\mathrm{Al}$ powder and produce $\mathrm{AlCl}_{3}$ gas. The mobility of the $\mathrm{AlCl}_{3}$ gas is much higher compared to the solid $\mathrm{Al}$ powder. Meanwhile, the $\mathrm{HCl}$ gas could also turn a dense $\mathrm{MgO}$ film into a loose one, which is preferred by the $\mathrm{AlCl}_{3}$ gas in order to pass through the oxide film and arrive at the magnesium alloy matrix. As a result, the Al-rich intermetallic layer formed on the magnesium alloy substrate.

While the $\mathrm{NH}_{4} \mathrm{Cl}$ content should be limited to a reasonable region. Excess ammonium chloride powder could produce a large amount of gas which could dilute the metallic halides, cause vibrating mixed powder and erode the as-formed intermetallic layer. Moreover, excess ammonium chloride powder could also cause material waste, air pollution, and device degradation et al. To utilize the 
ammonium chloride powder effectively, it is suggested that the $\mathrm{NH}_{4} \mathrm{Cl}$ content should be no more than $10 \mathrm{wt}$ \% of the overall weight of the diffusion source in the diffusion alloying process on the AZ91D magnesium alloy.

Author Contributions: Conceptualization, D.L.; Software, D.L.; Validation, D.L.; Formal Analysis, D.L.; Investigation, Q.J. and M.Z.; Resources, Y.H. and B.H.; Data Curation, D.L.; Writing-Original Draft Preparation, D.L.; Writing-Review and Editing, D.L.; Visualization, D.L.; Supervision, J.Z., Y.H. and B.H.; Project Administration, D.L.; Funding Acquisition, D.L.

Funding: This research was funded by the Applied Research Program of Qingdao (Grant number: 17-1-1-22-jch) and the Key Research \& Development Program of Shandong Province (Grant number: 2018GSF117039).

Acknowledgments: The authors would like to thank all the anonymous reviewers for their kind help and useful advice.

Conflicts of Interest: The authors declare no conflict of interest.

\section{References}

1. Zhu, Y.Y.; Chang, W.H.; Zhang, S.F.; Song, Y.W.; Huang, H.D.; Zhao, R.F.; Li, G.Q.; Zhang, R.F.; Zhang, Y.J. Investigation on corrosion resistance and formation mechanism of a $\mathrm{P}-\mathrm{F}-\mathrm{Zr}$ contained micro-arc oxidation coating on AZ31B magnesium alloy using an orthogonal method. Coatings 2019, 9, 197. [CrossRef]

2. Chen, J.; Kang, K.; Song, Y.W.; Han, E.H.; Ma, S.D.; Ao, J.Q. Corrosion behavior of hydrotalcite film on AZ31 alloy in simulated body fluid. Coatings 2019, 9, 113. [CrossRef]

3. Lu, D.Z.; Huang, Y.L.; Jiang, Q.T.; Zheng, M.; Duan, J.Z.; Hou, B.R. An approach to fabricating protective coatings on a magnesium alloy utilising alumina. Surf. Coat. Technol. 2019, 367, 336-340. [CrossRef]

4. Yang, H.Y.; Guo, X.W.; Wu, G.H.; Ding, W.J.; Birbilis, N. Electrodeposition of chemically and mechanically protective Al-coatings on AZ91D Mg alloy. Corros. Sci. 2011, 53, 381-387. [CrossRef]

5. Xie, J.S.; Zhang, J.H.; Liu, S.J.; Li, Z.H.; Zhang, L.; Wu, R.Z.; Hou, L.G.; Zhang, M.L. Hydrothermal synthesis of protective coating on $\mathrm{Mg}$ alloy for degradable implant applications. Coatings 2019, 9, 160. [CrossRef]

6. Zhang, X.C.; Wang, J.X.; Zhang, C.Y.; Liu, B.; Jiang, P.; Zhao, Y.; Buhe, B.; Zhang, T.; Meng, G.Z.; Wang, F.H. Formation process of an $\mathrm{LDH}$ coating on magnesium alloy by a $\mathrm{CO}_{2}$ pressurization method. Coatings 2019, 9, 47. [CrossRef]

7. Shaha, S.K.; Dayani, S.B.; Xue, Y.N.; Pang, X.; Jahed, H. Improving corrosion and corrosion-fatigue resistance of AZ31B cast $\mathrm{Mg}$ alloy using combined cold spray and top coatings. Coatings 2018, 8, 443. [CrossRef]

8. Ma, Y.P.; Xu, K.W.; Wen, W.X.; He, X.P.; Liu, P.F. The effect of solid diffusion surface alloying on properties of ZM5 magnesium alloy. Surf. Coat. Technol. 2005, 190, 165-170. [CrossRef]

9. Hirmke, J.; Zhang, M.X.; St John, D.H. Influence of chemical composition of Mg alloys on surface alloying by diffusion coating. Metall. Mater. Trans. A 2012, 43, 1621-1628. [CrossRef]

10. He, M.F.; Liu, L.; Wu, Y.T.; Tang, Z.X.; Hu, W.B. Improvement of the properties of AZ91D magnesium alloy by treatment with a molten $\mathrm{AlCl}_{3}-\mathrm{NaCl}$ salt to form an $\mathrm{Mg}$-Al intermetallic surface layer. J. Coat. Technol. Res. 2009, 6, 407-411. [CrossRef]

11. Mola, R. The properties of $\mathrm{Mg}$ protected by $\mathrm{Al}$ - and $\mathrm{Al} / \mathrm{Zn}$-enriched layers containing intermetallic phases. J. Mater. Res. 2015, 30, 3682-3691. [CrossRef]

12. Zhong, C.; Liu, F.; Wu, Y.T.; Le, J.J.; Liu, L.; He, M.F.; Zhu, J.C.; Hu, W.B. Protective diffusion coatings on magnesium alloys: A review of recent developments. J. Alloys Compd. 2012, 520, 11-21. [CrossRef]

13. Chang, H.W.; Zhang, M.X.; Atrens, A.; Huang, H. Nanomechanical properties of Mg-Al intermetallic compounds produced by packed powder diffusion coating (PPDC) on the surface of AZ91E. J. Alloys Compd. 2014, 587, 527-532. [CrossRef]

14. Shigematsu, I.; Nakamura, M.; Saitou, N.; Shimojima, K. Surface treatment of AZ91D magnesium alloy by aluminum diffusion coating. J. Mater. Sci. Lett. 2000, 19, 473-475. [CrossRef]

15. Lu, D.Z.; Zhang, Q.C.; Wang, X.T.; Yang, L.H.; Ma, X.M.; Wang, W.C.; Huang, Y.L. Intermetallic layer obtained by the compact powder diffusion alloying method on AZ91D magnesium alloy in air. Surf. Coat. Technol. 2017, 309, 986-993. [CrossRef]

16. Lu, D.Z.; Zhang, Q.C.; Wang, W.C.; Guan, F.; Ma, X.M.; Yang, L.H.; Wang, X.T.; Huang, Y.L.; Hou, B.R. Effect of cooling rate and the original matrix on the thermal diffusion alloyed intermetallic layer on magnesium alloys. Mater. Des. 2017, 120, 75-82. [CrossRef] 
17. Xiang, Z.D.; Datta, P.K. Kinetics of low-temperature pack aluminide coating formation on alloy steels. Metall. Mater. Trans. A 2006, 37, 3359-3365. [CrossRef]

18. Lu, T.; Yao, D.Z.; Zhou, C.G. Low-temperature formation of aluminide coatings on Ni-base superalloys by pack cementation process. Chin. J. Aeronaut 2010, 23, 381-385. [CrossRef]

19. Hu, G.X.; Xu, Z.X.; Liu, J.J.; Li, Y. Microstructure and corrosion resistance of simultaneous Al-Fe coating on copper by pack cementation. Surf. Coat. Technol. 2009, 203, 3392-3397. [CrossRef]

20. Park, H.H.; Lee, K.T.; Shin, H.S. Simultaneous chromizing-aluminizing diffusion coating of austenitic stainless steel by a two-step CVD process. Oxid. Met. 1998, 50, 377-387. [CrossRef]

21. Monas, A.; Shchyglo, O.; Kim, S.J.; Yim, C.D.; Höche, D.; Steinbach, I. Divorced eutectic solidification of Mg-Al alloys. JOM 2015, 67, 1805-1811. [CrossRef]

22. Tan, Q.Y.; Atrens, A.; Mo, N.; Zhang, M.X. Oxidation of magnesium alloys at elevated temperatures in air: A review. Corros. Sci. 2016, 112, 734-759. [CrossRef]

23. Czerwinski, F. The reactive element effect on high-temperature oxidation of magnesium. Int. Mater. Rev. 2015, 60, 264-296. [CrossRef]

(C) 2019 by the authors. Licensee MDPI, Basel, Switzerland. This article is an open access article distributed under the terms and conditions of the Creative Commons Attribution (CC BY) license (http://creativecommons.org/licenses/by/4.0/). 